\title{
CONNECTING THE DOTS BETWEEN SCIENCE AND BUSINESS
}

\author{
SCIENCE AND BUSINESS ARE OFTEN TREATED AS TWO SEPARATE DISCIPLINES, \\ WHICH LEADS TO PROBLEMS. SCIENTISTS MAY LACK THE BUSINESS SENSE TO \\ CONVERT THEIR RESEARCH INTO SOMETHING PRODUCTIVE, WHILST BUSINESS \\ PROFESSIONALS MAY LACK THE SCIENTIFIC KNOWLEDGE NEEDED TO MAKE \\ EVIDENCE-BASED DECISIONS. WESTMINSTER COLLEGE'S ENVIRONMENTAL \\ PROJECT MANAGEMENT ACADEMY (EPMA) AIMS TO BRIDGE THIS DIVIDE
}

Liberal arts institutions prepare students to reason logically, think critically, communicate effectively, and act ethically. However, while STEM graduates often enter the workforce with plenty of knowledge of their area of study, they may lack critical business and project management-related skills, such as communication and leadership skills. On the flipside, graduates of subjects such as business can have highly developed business acumen but can lack the basic scientific literacy that has an important role in the workplace.

Westminster College, situated in Pennsylvania, USA, launched the Environmental Project Management Academy (EPMA) to address this. The EPMA is funded by the National Science Foundation and is run by three professors, Dr Helen Boylan, Dr Alison DuBois, and $\mathrm{Mr}$ Brian Petrus, who have combined their diverse areas of expertise to ensure that students leave the EPMA with a well-rounded skillset that prepares them for the working world.

\section{The environmental science course} emphasises scientific literacy and the major environmental issues facing our planet. The business administration course develops the competencies and skills needed to effectively manage a project's life cycle by understanding the project's scope, including associated project costs and cohesive team functioning. The cross-disciplinary cluster course also includes a two-hour weekly leadership seminar embedded into the course meeting times, during which students further develop intangible skills (such as communication skills and training in team dynamics) that are applicable to the team-based project work.

Through the EPMA programme, students collaborate with community stakeholders as they integrate knowledge of environmental science, project management and intangible skills with project work on environmental issues relevant to the region.

\section{THE IMPORTANCE OF CROSS \\ DISCIPLINARY LEARNING}

"College classes are often taught in isolation and exclusively by discipline," says Dr DuBois. "We wanted to show the inter-connections between environmental science, project management, and leadership. The three of us collaborate in our teaching, so our projects share a common thread through all three disciplines."

Dr Boylan believes that combining these skillsets makes students more desirable as future employees. "Employers in the modern world value collaboration," she says. "The complex problems that we face today, such as climate change, the pandemic or the role of artificial intelligence, require people from different disciplines to collectively solve problems. Our programme teaches students from STEM or business backgrounds how to communicate with each other. The projects require both perspectives, so collaboration is vital."
WHY SCIENCE IS IMPORTANT FOR EVERYONE

"It is my belief that almost all future jobs will require a basic understanding of science and math," says Mr Petrus. "STEM literacy fosters creativity and critical thinking skills, which encourages teamwork and experimentation - important skills in real-world business environments."

The world is also becoming more cross-sectoral, especially as businesses' environmental footprints fall under increasing scrutiny. "Many businesses today are really developing their sustainability practices," says Dr DuBois. "Having a background in STEM alongside business acumen helps create a more wellrounded professional."

A growing reliance on technology also calls for people able to understand what it all means. "In the high-tech, data-driven world that we live in, people need to be able to look at data or figures and make sense of them," says Dr Boylan. "We need to be able to critically analyse conclusions and methodology, which STEM literacy can help with."

\section{EPMA PROJECTS}

The EPMA has undertaken three projects so far. Each project examined the underlying science of a topic and the feasibility of its implementation in a real-world setting. They have covered prospective solar panels in the college's borough, collecting and selling 
recovered minerals from acid mine drainage and industrial hemp operations.

"The industrial hemp project was my favourite," says Dr Boylan. "Our students developed website content related to the science of industrial hemp and completed a market analysis of potential hemp products. The students learnt about technologies associated with hemp products, such as biopolymers and composite plastics, and also how it could lead to economic growth in our region. This meant there was a real motivation for both students and faculty." Mr Petrus agrees, and mentions how it tied in to changes in federal legislation. "The project aligned with the 2018 Farm Bill and the associated regulatory changes in the industry, namely the legalisation of industrial hemp," he says. "We are seeing the foundations of a multi-billion-dollar industry."

Dr DuBois has a soft spot for another project. "Even though it wasn't as exciting as the hemp project, I really enjoyed investigating acid mine drainage," she says. "I spent a lot of time hiking growing up and this project led to me and the students learning a lot about the environment."

Now, they are getting started on a new project. "This year we are investigating sustainable business ventures into resources such as maple syrup, honey, cash crops and so on," says Mr Petrus. "This is in conjunction with underutilised wooded properties owned by Westminster College."

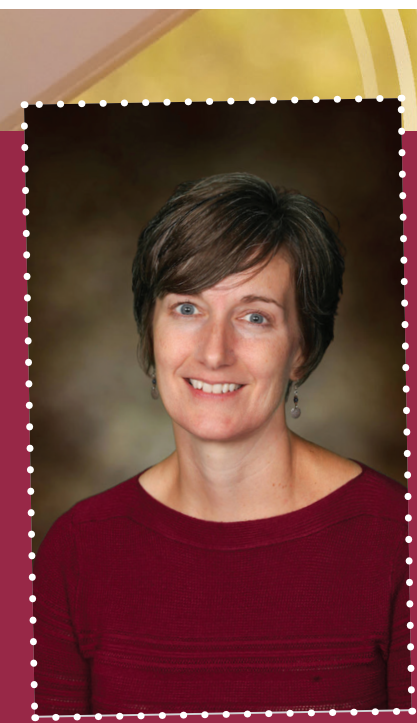

DR HELEN BOYLAN

Director of the Center for the Environment

\section{(n)}

\section{FIELD OF RESEARGH}

Chemistry and Environmental Science

\section{ROLE}

My role is to plan and deliver the environmental science content of the programme. I also develop lab experiences for the students, that help them develop their technical skills. I serve as the point of contact for our community project partners.

\section{INSPIRATION}

I grew up next to the Allegheny National Forest. It was my playground and my laboratory. I was fascinated by this environment and the critters it contained, which meant that environmental science appealed to me.

\section{HELFNS TOP TIPS FOR STUDENIS}

Be curious. Ask questions about the world and the people around you. Read up on the things you are interested in. Explore!

Embrace failure. In science, you learn as much - if not more - from your mistakes than you do your successes. Often, science isn't easy. Sometimes you just have to keep trying. Don't be afraid to try new or difficult things - it is always worth it in the end.

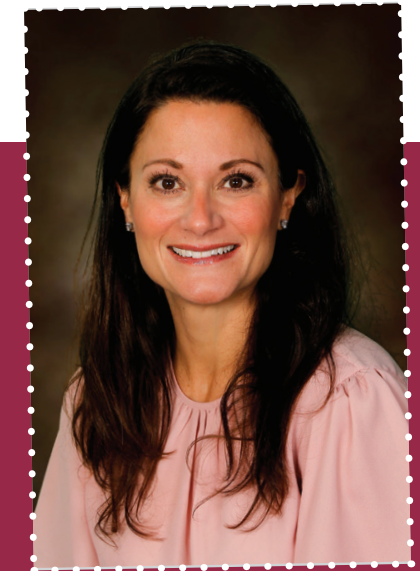

Di ALISON DUBOIS

Associate Professor/Director of Graduate School

\section{FIELD OF RESEARCH}

Burnout and Compassion Fatigue

\section{ROLE}

I teach a 10 -week leadership seminar. Students learn about leadership theories and traits, and work on building more effective communication and writing skills. The unique aspect about this part is that students engage in activities that make them feel vulnerable. This helps them to develop a deeper level of selfawareness, in addition to stronger emotional literacy skills.

\section{INSPIRATIOK}

I really love to teach. I get inspired by my students' enthusiasm and risk-taking when they work on difficult tasks. It is motivating to watch the students grow as they stretch themselves intellectually.

\section{ALSONS TOP TIP FOR STUDENIS}

Anxiety is not a bad thing. Choose to get out of your comfort zone and try something challenging. 


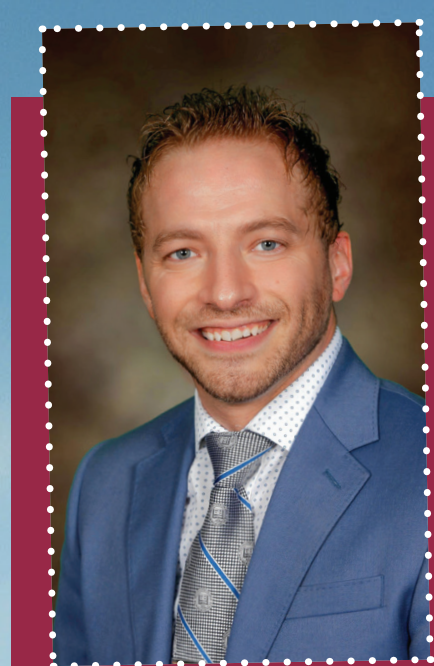

MR

\section{BRIAN PETRUS}

Assistant Professor of

Business Administration

\section{FIELD OF RESEARGH}

Project Management, Human Resource Management

\section{ROLF}

I act as a co-investigator for the EPMA project, developing and delivering the portion of the curriculum that focuses on project management. I have found the EPMA programme to be extremely rewarding. In addition to working directly with students, it gives me the opportunity to work alongside two of the college's brightest and most student-centric professors.

\section{INSPIRATIOK}

My father has always been my greatest source of inspiration. He is retired from the Natural Resource Conservation Service and is a true jack-of-all-trades - he has provided me with innumerable life lessons that I often draw upon in the classroom. In all that I do, I strive to be the man that my father has taught me to be.

\section{BRIANS TOP TIP FOR STUDENIS}

You can spend money and always make it back. When you spend time, however, you never get it back. So, spend your time wisely, doing the things you love and with people worth spending it with.

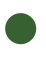 MEET THREE EPMA STUDENTS}

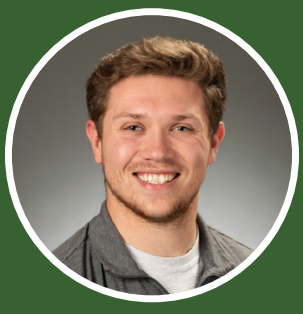

NAME: Samuel Hockenberry

MAJOR: Mathematics/Computer Information Systems (Double Major)

CURRENT ROLE: Lead Analyst Full Stack Developer at BNY Mellon do not have the technology to fully replace our current electricity infrastructure.

I found that project management is heavily based on two concepts: communication and documentation. These can drive a project to success or can lead it to failure if not utilised properly. Our teams had to keep detailed documentation and open communication throughout the project.

I attribute this course to 'jump-starting' my career. By the time it came to an end, I could understand a project's lifecycle and confidently apply that knowledge outside of the classroom. This helped me every day during my summer internship, which led me to secure the position I am in today.

In the short term, I would like to become a product manager for a project, where the skills I learned in the course would come in useful. In the longer term, I hope to continue my education and receive a Master's degree in Computer Science, and eventually a PhD in Mathematics.

I would advise anyone to take the course! It is the closest students can get to 'real-world' project development outside of the workplace.

This course gave me new insights into the world of renewable energy. Although it would be great to use solar panels everywhere, we simply 
NAME: Reilly DeGeorge

MAJOR: Environmental Science

CURRENT ROLE: Industrial

Laboratory Chemist were unable to collaborate with the farmers, but we still got great hands-on experience.

This project has helped me get a better understanding of the environment through learning about real-world situations. We were able to go out and talk directly to the people they affected.

The programme has taught me how to communicate effectively within small teams, how to manage and lead groups of people, how to communicate better, and how to make pivotal decisions.

I took the EPMA course because I wanted to further my knowledge in topics related to the environment and project management, and to gain more real-life and hands-on experiences.

I took part in researching industrial hemp, such as its associated agricultural science, the legalisation and regulations surrounding hemp, and the business of selling and distributing hemp products in the US. This class challenged me to use my voice and participate in discussions and meetings. I also learnt how to use new software and effective working within teams.

We collaborated with DON Services Inc. and provided them with information on the hemp industry. Due to the pandemic, we
I am currently working within a small team at an industrial laboratory and am constantly communicating with team members and truck drivers. The EPMA really helped me develop better communication and organisational skills. I am working towards getting my MBA and can see myself following a career in industry or the government, specifically in the environmental field.

I would advise students to get as much real-world experience as they can. The EPMA can grant you many opportunities - use them and learn from them. Build relationships with as many professors and environmental students as you can, because you can really learn a lot from them.

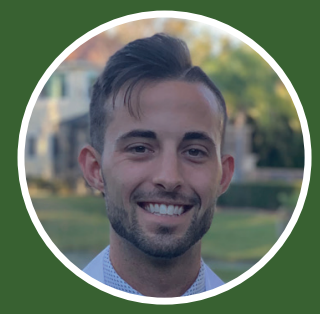

NAME: Zach Fryda

MAJOR: Biology

CURRENT ROLE: Medical Student, LECOM Bradenton
Being a biology major, I had very little exposure to business and project management in academia, so EPMA seemed like the perfect opportunity to learn these skills in a familiar context.

My project involved evaluating the feasibility of implementing solar energy in New Wilmington Borough. The project relied upon the integration of three different perspectives, each of which provided its own set of challenges. Morally, I was challenged to actively think about the impact of my choices and how my sphere of influence affected group dynamics and my leadership qualities. Scientifically, I was challenged to understand the science behind not only solar energy, but the wider field of sustainable energy too. Financially, the project challenged me to appreciate the fiscal responsibilities associated with STEM research and developments.

The project's primary stakeholder was the Borough of New Wilmington and its associated board members. By working with local government officials, we applied educational concepts into actual scenarios. This not only prepared us for similar applications in the future, but also allowed us to expand upon our political skills.

Prior to EPMA, my understanding of sustainable energy was very limited. One of the most enlightening topics we discussed was the environmental impact of manufacturing solar energy. When I took the course in 2017, the environmental impacts of the manufacture of some solar panels was only just offset by the resultant clean energy. This insight taught me to think critically about technologies labelled as clean, and the need to develop surrounding infrastructure as well as the products themselves.

I had practical experience of project management prior to EPMA, specifically through working as a seasonal warehouse manager at a major fireworks store. However, putting academic context to my skills allowed me to improve them immensely and provided me with the framework to extrapolate them to other scenarios.

I credit this course for the sole, most significant growth of my leadership style and personal development. It made me evaluate and improve my actions and contributions as a leader and group member. Although my scientific knowledge grew, it is the leadership techniques I learnt that now help me during my medical school education. I cannot emphasise enough the importance of this aspect of EPMA in helping me succeed as a graduate, medical student, and future physician.

I am currently a second-year medical student and plan on obtaining a Master's of Public Health. After medical school, I hope to become a Paediatric Infectious Disease Physician. I want to impact public health on a global scale. Ultimately, I hope to work for the Centers for Disease Control and Prevention, where I can not only treat patients but can also impact policy that could positively affect people around the globe.

I would advise prospective students to keep an open mind and not only focus on content they deem 'relevant' to their area of study. Had I not fully engaged with every opportunity presented to me, I could have unknowingly shut doors that would help me meet my future goals. 